\title{
Phosphorus loss by surface runoff in no-till system under mineral and organic fertilization
}

\author{
Oromar João Bertol ${ }^{1 *}$; Nivaldo Eduardo Rizzi²; Nerilde Favaretto²; Maria do Carmo \\ Lana $^{3}$ \\ ${ }^{1}$ EMATER, R. da Bandeira, 500 - 80035-270 - Curitiba, PR - Brasil. \\ ${ }_{3}^{2} U F P R$ - Depto. de Solos e Engenharia Agrícola, R. dos Funcionários, 1540 - 80035-050 - Curitiba, PR - Brasil. \\ ${ }^{3}$ UNIOESTE - Centro de Ciências Agrícolas, R. Pernambuco, 1777 - 85960-000 - Marechal Cândido Rondon, \\ PR - Brasil. \\ *Corresponding author <oromar@emater.pr.gov.br>
}

\begin{abstract}
The no-till system has been intensively used in the state of Paraná, Brazil, and it has increased the nutrients level at the soil surface. This has contributed for nutrient losses via runoff and consequently, offsite water pollution. The objective of this study was to evaluate phosphorus loss in surface runoff by simulated rainfall on an Oxisol, under no-till system following application of mineral fertilizer and liquid swine manure. Nitrogen, soil and water losses from the same study are reported in a separated paper. The application of liquid swine manure, compared with mineral fertilization, increased runoff concentration of total $\mathrm{P}$, particulate $\mathrm{P}$ and dissolved reactive $\mathrm{P}$ by $193 \%, 111 \%$ and $506 \%$, respectively, averaged for all rainfall intensities. Independently on the fertilizer source, the highest rainfall intensity provided the greatest concentration and loads of $\mathrm{P}$ in runoff.
\end{abstract}

Key words: liquid swine manure, water quality, eutrophication, soil erosion, conservation tillage

\section{Perda de fósforo via escoamento superficial no sistema plantio direto sob adubação mineral e orgânica}

\begin{abstract}
RESUMO: O sistema plantio direto tem sito intensivamente utilizado no Estado do Paraná - Brasil o qual tem aumentado os níveis de nutrientes na superfície do solo. Isto tem contribuído para a perda de nutrientes via escoamento superficial e consequentemente com a poluição não pontual das águas. Avaliou-se a perda de fósforo via escoamento superficial ocasionado por chuva simulada sobre um Latossolo originário de basalto, em sistema plantio direto submetido à aplicação de fertilizante mineral e dejeto líquido de suíno. As perdas de nitrogênio, solo e água deste mesmo estudo foram publicadas em outro artigo. A aplicação de dejeto líquido suíno, comparado com o fertilizante mineral, aumentou a concentração de $\mathrm{P}$ total, $\mathrm{P}$ particulado e $\mathrm{P}$ dissolvido reativo em $193 \%$, $111 \%$ e $506 \%$, respectivamente, na média das chuvas. Independentemente da fonte de fertilizante, a chuva de maior intensidade proporcionou maior concentração e quantidade perdida de P no escoamento superficial.

Palavras-chave: dejeto líquido de suíno, qualidade de água, eutrofização, erosão do solo, sistema conservacionista
\end{abstract}

\section{Introduction}

Runoff is the main processes involved in the nonpoint water pollution (Parry, 1998) transporting soluble and particulate nutrients. The nitrogen $(\mathrm{N})$ and phosphorus $(\mathrm{P})$ transported by runoff have an important role in the eutrophication process (Eghball and Gilley, 1999; Correll, 1998; Daniel et al., 1998; Sharpley et al., 1994). Although both $\mathrm{N}$ and $\mathrm{P}$ are essential for the algae development, $\mathrm{P}$ is considered the most limiting to organic production in water. Considering this, the water eutrophication control has been focused at the $\mathrm{P}$ source and P transport factors (Sharpley et al., 2001; Shigaki et al., 2006a; Shigaki et al., 2007).

The intensive use of mineral and organic fertilizers in crop production has caused a nutrient accumulation, mainly at the soil surface (Cassol et al., 2002; McDowell and Sharpley, 2001; Sharpley et al., 2001), especially in the no-till system (Hernani et al., 1999; Ismail et al., 1994;
Sharpley et al., 1994; Laflen and Tabatabi, 1984), and the soil surface nutrient enrichment increases the potential for nutrient loss by runoff (Kimmell et al., 2001; Pote et al., 1999; Ginting et al., 1998; Sharpley et al., 1991).

Manured soils have a great potential for $\mathrm{P}$ loss by runoff (Allen and Mallarino, 2008; Smith et al., 2001). However, it is related to several factors as $\mathrm{P}$ sources (Shigaki et al., 2006b; Kleinman et al., 2002), rainfall intensities (Shigaki et al., 2007; Kleinman et al, 2006), and the time between manure application and rainfall (Shigaki et al., 2007; Shigaki et al., 2006b). The short period between liquid manure application and rainfall has increased the P losses (Mori et al., 2009; Allen and Mallarino, 2008) probably because of the runoff increases (Bertol et al., 2007; Peles, 2007) as a consequence of the surface sealing caused by the manure physical and chemical effect (Bundy et al., 2001; Smith et al., 2001). To mitigate the agricultural water quality problems, best management practices, including runoff control as well 
Bertol et al.

as use and management of organic fertilizers, have been used in several countries (Shigaki et al., 2006a).

The objective of this study was to evaluate P loss by surface runoff, with simulated rainfall, on a soil under no-till system following a recently application of mineral fertilizer or swine liquid manure as to contribute for the establishment of Brazilian best soil management practices. Nitrogen, soil and water losses were also recorded but have been reported separately (Bertol et al., 2005; Bertol et al., 2007).

\section{Material and Methods}

The field experiment was carried out in Marechal Cândido Rondon, Western Paraná State, Brazil, at 194.290 and 7.283.460 UTM coordinates. The experiment was carried out in an Oxisol (Latossolo Vermelho Eutroférrico típico according to the Brazilian soil classification) with $0.045 \mathrm{~m} \mathrm{~m}^{-1}$ slope under a no-till system for five years. Some of the physical and chemical properties analyzed into the $0-0.2 \mathrm{~m}$ layer was: $5.4 \mathrm{pH} \mathrm{CaCl}_{2}$; 0 mmol $_{\mathrm{c}} \mathrm{kg}$ of exchangeable $\mathrm{Al}^{++} ; 45 \mathrm{mmol} \mathrm{kg}_{\mathrm{c}} \mathrm{kg}^{-1}, 22$ mmol $\mathrm{kg}^{-1}$ and $3.4 \mathrm{mmol} \mathrm{kg}^{-1}$ of exchangeable $\mathrm{Ca}^{++}$; $\mathrm{Mg}^{++}$; de $\mathrm{K}^{+}$, respectively; $54.1 \mathrm{mg} \mathrm{kg}^{-1} \mathrm{P}$ (Mehlich I); 729 $\mathrm{g} \mathrm{kg}^{-1}$ clay; $188 \mathrm{~g} \mathrm{~kg}^{-1}$ silt; $83 \mathrm{~g} \mathrm{~kg}^{-1}$ sand; $1.29 \mathrm{~kg} \mathrm{dm}^{-3}$ bulk density; $2.74 \mathrm{~kg} \mathrm{dm}^{-3}$ particle density; $0.41 \mathrm{dm}^{3} \mathrm{dm}^{-3}$ microporosity; $0.11 \mathrm{dm}^{3} \mathrm{dm}^{-3}$ macroporosity; and 0.52 $\mathrm{dm}^{3} \mathrm{dm}^{-3}$ total porosity. Bulk density was determined by the core method; total porosity was obtained by saturation volume; microporosity by the tension table at 60 $\mathrm{cm}$ and macroporosity calculated by the difference between total and microporosity (EMBRAPA, 1997).

The treatments, with four replicates, were: (NPK) A commercial composed NPK mineral fertilizer (31, 107 , and $152 \mathrm{~g} \mathrm{~kg}^{-1}$ of $\mathrm{N}, \mathrm{P}$ and $\mathrm{K}$, respectively, constituted of monoammonium phosphate, single superphosphate, triple superphosphate and potassium chloride) applied to the soil surface at rate of $200 \mathrm{~kg} \mathrm{ha}^{-1}$; (LSM) Liquid swine manure $\left(31.9 \mathrm{~g} \mathrm{~L}^{-1}\right.$ of dry matter and $0.28 \mathrm{~g}$ $\mathrm{L}^{-1}$ of total $\mathrm{P}$ ) applied at the soil surface at a rate of 60 $\mathrm{m}^{3} \mathrm{ha}^{-1}$; and (C) - Control, unamended soil. The mineral fertilizer and liquid swine manure were applied at the rates used by the farmers in that region in soil with high soil P level, and provided, 21.4 and $16.8 \mathrm{~kg} \mathrm{ha}^{-1}$ of total $P$, respectively.

After the wheat harvest, a sowing procedure was performed with an implement containing chisel coulters spaced at $40 \mathrm{~cm}$. This was applied up and down the slope in order to simulate a usual condition in areas without terraces and consequently, to create a worst case scenario for runoff and soil transportation by water erosion. Fertilizers were applied after this procedure in experimental plots of $1 \mathrm{~m}$ by $1 \mathrm{~m}$ bounded with metallic borders. For the runoff sampling, a trench was opened, with dimensions and depth sufficient to hold a reservoir with a capacity of $25 \mathrm{~L}$.

The simulated rainfall started $16 \mathrm{~h}$ after the application of the mineral fertilizer and the liquid swine manure using a rainfall simulator with rotating booms
(Swanson, 1965). Initially, a soil wetting rainfall at 57 $\mathrm{mm} \mathrm{h}^{-1}$ was applied during $38 \mathrm{~min}$. Thirty minutes later, a series of three simulated rains (R1, R2, and R3) was applied with intensity of 72,63 , and $117 \mathrm{~mm} \mathrm{~h}^{-1}$, respectively, each during 20 min with a 30 -min interval. These intensities were used based on the maximum rain volume during one day with a return period of 20 years and the reason to use a series of rain with three different intensities was to simulate the region's condition.

After each rain (R1, R2, and R3), a runoff sample was collected for total and soluble phosphorus determination. Remaining runoff was kept in the respective reservoirs for $24 \mathrm{~h}$. After this period, another sample was taken from the supernatant to determine the total suspended $P$. The total runoff represents the total sediments plus the water from rainfall. These sediments are the sum of the decanted plus the suspended sediments. While the suspended runoff represents the rainfall water plus the sediments suspended after $24 \mathrm{~h}$.

Dissolved reactive $P$ (DRP) was determined in a sample filtered through a 0.45 im filter by the ascorbic acid method (APHA, 1995). Total P (TP) and total suspended $\mathrm{P}$ (TPs) were determined in an unfiltered sample by digestion with hydrofluoric and perchloric acids (Jackson, 1958). After the digestion procedure, the TP and TPs samples were also analyzed by the ascorbic acid method (APHA, 1995). The particulate P (PP) and particulate suspended P (PPs) was obtained by subtracting the concentration of dissolved reactive $\mathrm{P}$ from the total P, and total suspended P.P loss in runoff was obtained from the $\mathrm{P}$ concentration and the runoff volume for each rain, and the percentage of loss was calculated considering the amount of total $\mathrm{P}$ applied in each treatment.

The statistical analyses were done using a linear model based on Federer (1993). The residue normality was applied using the Shapiro- Wilk W-test according to Royston (1992), and the mean multiple comparisons were done by orthogonal contrasts using the F test (Steel et al., 1997).

\section{Results and Discussion}

\section{Phosphorus concentration}

The application of liquid swine manure increased the concentration of DRP in the runoff from the three simulated rainfalls (Table 1). DRP concentrations in the liquid swine manure treatment were from 5 to 8 times greater than the NPK treatment and from 12 to 20 times greater than the unamended soil (Table 1), in agreement with the findings of Allen and Mallarino (2008). These differences can be attributed to blockage of the P adsorption sites in the clay minerals through organic acids from manure with and consequently, increase $\mathrm{P}$ in soil solution (Andrade et al., 2003). Also, the greater concentration of DRP in runoff in soil with liquid swine manure compared with NPK fertilization indicates that the suspended sediments adsorbed the applied $\mathrm{P}$ as fertilizer during the runoff process (Sharpley et al., 1994). 
Table 1 - Average concentration and orthogonal contrast of dissolved reactive P (DRP) and particulate P (PP) in runoff, particulate $P$ in suspended sediment (PPs), and total $\mathrm{P}(\mathrm{TP})$ in runoff in the three simulated rainfalls (R1, $\mathrm{R} 2$, and R3) applied on the organic fertilization (LSM), mineral fertilization (NPK), and control (C) treatments.

\begin{tabular}{|c|c|c|c|c|c|}
\hline \multirow{3}{*}{ Rainfall } & \multicolumn{3}{|c|}{ Treatment } & \multicolumn{2}{|l|}{ Contrast } \\
\hline & LSM & NPK & $\mathrm{C}$ & C vs LSM, NPK & LSM vs NPK \\
\hline & \multicolumn{3}{|c|}{ mg L ${ }^{-1} \mathrm{DRP}$} & \multicolumn{2}{|c|}{$\operatorname{Pr}>\mathrm{F}$} \\
\hline $\mathrm{R} 1$ & $4.93 \pm 0.36$ & $0.83 \pm 0.045$ & $0.21 \pm 0.05$ & $<0.0001$ & $<0.0001$ \\
\hline $\mathrm{R} 2$ & $3.53 \pm 0.43$ & $0.74 \pm 0.06$ & $0.25 \pm 0.06$ & 0.0002 & $<0.0001$ \\
\hline R3 & $4.07 \pm 0.22$ & $0.48 \pm 0.09$ & $0.35 \pm 0.05$ & $<0.0001$ & $<0.0001$ \\
\hline Contrast & \multicolumn{3}{|c|}{$\operatorname{Pr}>F$} & & \\
\hline R1 vs R2, R3 & 0.026 & 0.032 & 0.184 & & \\
\hline \multirow[t]{2}{*}{ R2 vs R3 } & 0.307 & 0.025 & 0.203 & & \\
\hline & \multicolumn{3}{|c|}{$\mathrm{mg} \mathrm{L}^{-1} \mathrm{PP}$} & \multicolumn{2}{|c|}{$\operatorname{Pr}>\mathrm{F}$} \\
\hline R1 & $4.49 \pm 0.84$ & $2.34 \pm 0.47$ & $1.96 \pm 0.37$ & 0.077 & 0.031 \\
\hline $\mathrm{R} 2$ & $3.33 \pm 0.04$ & $1.35 \pm 0.20$ & $1.76 \pm 0.29$ & 0.176 & 0.002 \\
\hline R3 & $9.41 \pm 1.42$ & $4.83 \pm 0.43$ & $3.49 \pm 0.79$ & 0.014 & 0.009 \\
\hline Contrast & & $\operatorname{Pr}>\mathrm{F}$ & & & \\
\hline R1 vs R2, R3 & 0.153 & 0.146 & 0.332 & & \\
\hline \multirow[t]{2}{*}{ R2 vs R3 } & 0.002 & 0.001 & 0.046 & & \\
\hline & \multicolumn{3}{|c|}{ mg L ${ }^{-1}$ PPs } & \multicolumn{2}{|c|}{$\operatorname{Pr}>\mathrm{F}$} \\
\hline R1 & $2.01 \pm 0.49$ & $0.49 \pm 0.13$ & $0.27 \pm 0.03$ & 0.022 & 0.005 \\
\hline $\mathrm{R} 2$ & na & na & na & & \\
\hline R3 & $1.27 \pm 0.18$ & $0.55 \pm 0.14$ & $0.30 \pm 0.04$ & 0.005 & 0.005 \\
\hline Contrast & & $\mathrm{Pr}>\mathrm{F}$ & & & \\
\hline \multirow[t]{2}{*}{ R1 vs R3 } & 0.294 & 0.770 & 0.539 & & \\
\hline & \multicolumn{3}{|c|}{ mg L-1 TP } & \multicolumn{2}{|c|}{$\operatorname{Pr}>\mathrm{F}$} \\
\hline $\mathrm{R} 1$ & $9.42 \pm 1.10$ & $3.16 \pm 0.46$ & $2.16 \pm 0.38$ & 0.001 & 0.0002 \\
\hline $\mathrm{R} 2$ & $6.87 \pm 0.81$ & $2.09 \pm 0.25$ & $2.01 \pm 0.34$ & 0.004 & 0.0001 \\
\hline R3 & $13.48 \pm 1.62$ & $5.31 \pm 0.45$ & $3.84 \pm 0.74$ & 0.002 & 0.0004 \\
\hline Contrast & & $\operatorname{Pr}>\mathrm{F}$ & & & \\
\hline $\mathrm{R} 1$ vs $\mathrm{R} 2, \mathrm{R} 3$ & 0.627 & 0.296 & 0.262 & & \\
\hline R2 vs R3 & 0.004 & 0.0003 & 0.034 & & \\
\hline
\end{tabular}

$\operatorname{Pr}>\mathrm{F}=\mathrm{p}$-value of statistics $\mathrm{F}$ for orthogonal contrasts; na = no analyzed; \pm = standard deviation.

High DRP concentration in the swine liquid manure treatment can also be explained by the increase of the runoff (Bertol et al., 2007) as a consequence of the possible surface sealing caused by the slurry application (Mori et al., 2009) with consequences on the soluble P transport of the (Bertol et al., 2007). The solid particle of the manure can close the soil macropores causing a surface sealing by physical obstruction. Evidence of nutrient losses affected by soil surface sealing due to slurry manures application has been shown at short and long time experiments (Gilley et al., 2007; Smith et al., 2001).

The amount of total $\mathrm{P}$ applied by swine manure was lesser than through mineral fertilization $\left(16.8 \mathrm{~kg} \mathrm{ha}^{-1}\right.$ and 21.4 of total P, respectively). Moreover, the amount of water soluble $\mathrm{P}$ also was lesser considering that the $\mathrm{P}$ water solubility in the mineral fertilizer is higher than in the swine manure. Kleinman et al. (2002) and Shigaki et al. (2006b) have shown that runoff $\mathrm{P}$ losses are closely related to the $\mathrm{P}$ water solubility in $\mathrm{P}$ sources. Particulate $\mathrm{P}(\mathrm{PP})$ concentration in runoff with application of liquid swine manure was greater than the NPK treatments in all rainfalls (Table 1). The greater PP concentration in the soil amended with liquid swine manure was probably due to the transportation of organic particles by runoff, which are highly enriched by $P$. The sediment enrichment during the runoff process by the DRP adsorption could also have contributed to this result (Sharpley et al., 1994), since the DRP concentration in the runoff was excessively greater in the liquid swine manure treatment (Table 1).

Fertilizations also affected the concentrations of particulate $\mathrm{P}$ in the suspended sediments in the runoff (PPs) (Table 1). In all rainfalls, the concentration of PPs was greater in treatment with swine liquid manure compared 
Bertol et al.

with the mineral fertilization and unamended soil (Table 1). These results possibly are due to the great amount of solid particles of swine manure suspended in the runoff, which were rich in $\mathrm{P}$, as well as the capacity of these particles to adsorb soluble ions from the runoff, such as phosphates.

The sediments transported by runoff have different sized particles and this affects the settling velocity. Finer and less dense particles, such as clay minerals and organic matter, present a slow sedimentation rate and remain suspended in water for longer periods. Considering this, the PPs loss has a great environmental importance because, as the DRP, it becomes a water diffuse pollution source far away from where the loss occurred. So, it is important to use measures to retain the runoff in the field under no-till, as a "terraces" system, for example, since the runoff in no-till transports mainly soluble nutrients and suspended sediments.

The concentration of total P (TP) in runoff was influenced by treatments, similar to the behavior of DRP concentration, yet, with less difference among treatments (Table 1). The TP concentrations in all rainfalls with swine manure application were about three times greater than for the NPK and control treatments, even with less $\mathrm{P}$ applied by the swine manure in comparison to the mineral fertilization. This probably occurred due to the transport of organic solid particles from manure remained on the soil surface which was not incorporated into the soil (Allen and Mallarino, 2008; Pierson et al., 2001; Smith et al., 2001). The P water solubility and the high runoff volume (Bertol et al., 2007) in the swine manure treatment can also have contributed to this result (Withers et al., 2001). This shows the risk of even low intensity rainfalls on P loss (Quinton et al., 2001), especially when the rainfall occurs immediately after the application of swine manure at the soil surface.

The rainfall intensities had a distinct effect in the concentration of different $\mathrm{P}$ forms. TP concentration in runoff was more affected by intensity than the DRP concentration, but with an inverse effect since the TP concentration increased as the rainfall intensity increased for the liquid swine manure and NPK treatments, and the DRP concentration decreased, especially in the NPK treatment (Table 1). Sharpley et al. (2001) reported that the increase in soil loss caused an increase in the TP and PP, and a decrease in DRP concentration. Sharpley et al. (1981) found an inverse relationship between DRP concentration and sediment concentration in runoff. According to them, the decrease in the DRP was a consequence of the soluble $\mathrm{P}$ reabsorption by the sediments transported during the erosion process. In our experiment, the soil loss was greater in the $\mathrm{R} 3$ rainfall (third rainfall with $117 \mathrm{~mm} \mathrm{~h}$ of intensity), independently of treatments (Bertol et al., 2007).

The TP concentration in runoff of the $\mathrm{R} 3$ rainfall (third rainfall with $117 \mathrm{~mm}$ h of intensity) was about 1.4, 1.7 and 1.8 times greater than the R1 rainfall (first rainfall with $72 \mathrm{~mm} \mathrm{~h}^{-1}$ of intensity) for the liquid swine manure, NPK fertilizer, and unamended treatments, respec- tively. These data indicate the effect of rainfall intensity as well as the soil hydrology in the TP concentration in runoff (Shigaki et al., 2007; Kleinman et al., 2006; Sharpley et al., 1994).

The third rainfall (intensity of $117 \mathrm{~mm} \mathrm{~h}^{-1}$ ) also caused greater PP concentration in the runoff for all treatments (Table 1). This can be explained by the higher intensity of this rainfall, transporting more sediment as soil and manure particles as shown by Bertol et al. (2007). This reinforces the importance of sediment transport on $\mathrm{P}$ losses, and the necessity to control soil erosion to avoid water eutrophication (Simard et al., 2000; Daniel et al., 1998; Sharpley et al., 1994).

Considering the environmental issues, the TP loss through runoff causes an important impact in a water body where it is deposited (Alberts and Spomer, 1985). According to the Brazilian legislation, TP concentration in lakes should not be greater than $0.02 \mathrm{mg} \mathrm{L}^{-1}$, and for rivers should not be greater than $0.1 \mathrm{mg} \mathrm{L}^{-1}$ (CONAMA, 2005). In our study, the environmental importance of TP loss by runoff was evident, since the highest $(13.48 \mathrm{mg}$ $\left.\mathrm{L}^{-1}\right)$ and the lowest $\left(2.01 \mathrm{mg} \mathrm{L}^{-1}\right)$ average of TP concentration in runoff (Table 1) were much higher than the limits to avoid eutrophication. The TP concentration even in the unamended soil was above the limit established to avoid eutrophication. These high TP concentrations in runoff can be explained by the high $\mathrm{P}$ soil level (54.1 mg kg${ }^{-1} \mathrm{P}$ Mehlich I). It is widely known that the no-till system causes a $\mathrm{P}$ accumulation at the soil surface (Kimmell et al., 2001; Soileau et al., 1994; Laflen and Tabatabi, 1984).

The percentage of total $\mathrm{P}$ as DRP was greater with liquid swine manure application compared with NPK and unamended treatments in all rains. However, the differences are more evident in the first and second rain (about $50 \%$ of TP is composed of DRP in the first rain and second rain) (Figure 1). DRP is readily available for aquatic organisms, and this high contribution of DRP allows to state that the liquid swine manure application in agricultural areas without vegetative or mechanical practices to control runoff greatly increases the risks of water degradation.

The lesser concentration of sediments in the runoff of the first and second rainfall (Bertol et al., 2007) can be one reason for a high percentage of DRP, since PP is related to sediments (Eghball and Gilley, 2001; Simard et al., 2000; Correll, 1998; Daniel et al., 1998). The lower sediment concentration (Bertol et al., 2007) was closely related to the lower PP and, as a consequence, the greater DRP. In the third rain, there was a higher percentage of TP as PP (Figure 1) reflecting higher sediment concentration in this rain (Bertol et al., 2007).

A low percentage of PP (Baker and Richards, 2002; Sharpley et al., 1994) is expected in no-till system because of the low sediment transport. However, in this experiment, PP represented more than $50 \%$ of the TP (Figure 1). This possible occurred due to the transport of sediments rich in $\mathrm{P}$ as manure and soil particles at the soil surface. It is interesting to explain that sediment trans- 
port was potentially increased by the sowing performed at the beginning of the experiment. In conservation or pastures systems, most of the TP is constituted by DRP, however in a conventional system, from 75 to $95 \%$ of TP is constituted by PP (Sharpley et al., 1994).

Besides the agronomical issues, it is important to consider the environmental problems related to nutrient losses. Although PP is considered a long-term potential source of eutrophication, depending of the condition, a great fraction of PP (up to $70 \%$ ) can also be readily available to aquatic organisms (Sonzogni et al., 1982). Sharpley et al. (1992) found that the PP bioavailability can vary from 9 to $69 \%$ depending on agricultural management. This indicates that in order to control diffuse water pollution from no-till systems, it is necessary to prevent runoff in the agricultural field by best management practices.

\section{Phosphorus load}

Less than $15 \%$ of to the $\mathrm{P}$ applied was lost in runoff (Figure 2), being greatly affected by fertilizer type and rainfall intensity. Even though more total $\mathrm{P}$ had been applied in the mineral fertilization $\left(21.4 \mathrm{~kg} \mathrm{ha}^{-1}\right)$ compared with the organic fertilization $\left(16.8 \mathrm{~kg} \mathrm{ha}^{-1}\right)$, the TP loss following swine manure application was 7.3, 8.5 and 4.5 times greater for R1 (first rain with intensity of $72 \mathrm{~mm} \mathrm{~h}^{-1}$ ), R2 (second rain with intensity of $63 \mathrm{~mm} \mathrm{~h}^{-1}$ ), and $\mathrm{R} 3$ (third and last rain with intensity of $117 \mathrm{~mm} \mathrm{~h}^{-1}$ ), respectively. These results are due to the combined effect of greater $\mathrm{P}$ concentration (Table 1) with higher runoff volume (Bertol et al., 2007) with application of liquid swine manure compared with the NPK treatment. Low P losses, usually less than $5 \%$ of the applied $\mathrm{P}$, are commonly found, especially in conservation tillage (Sharpley et
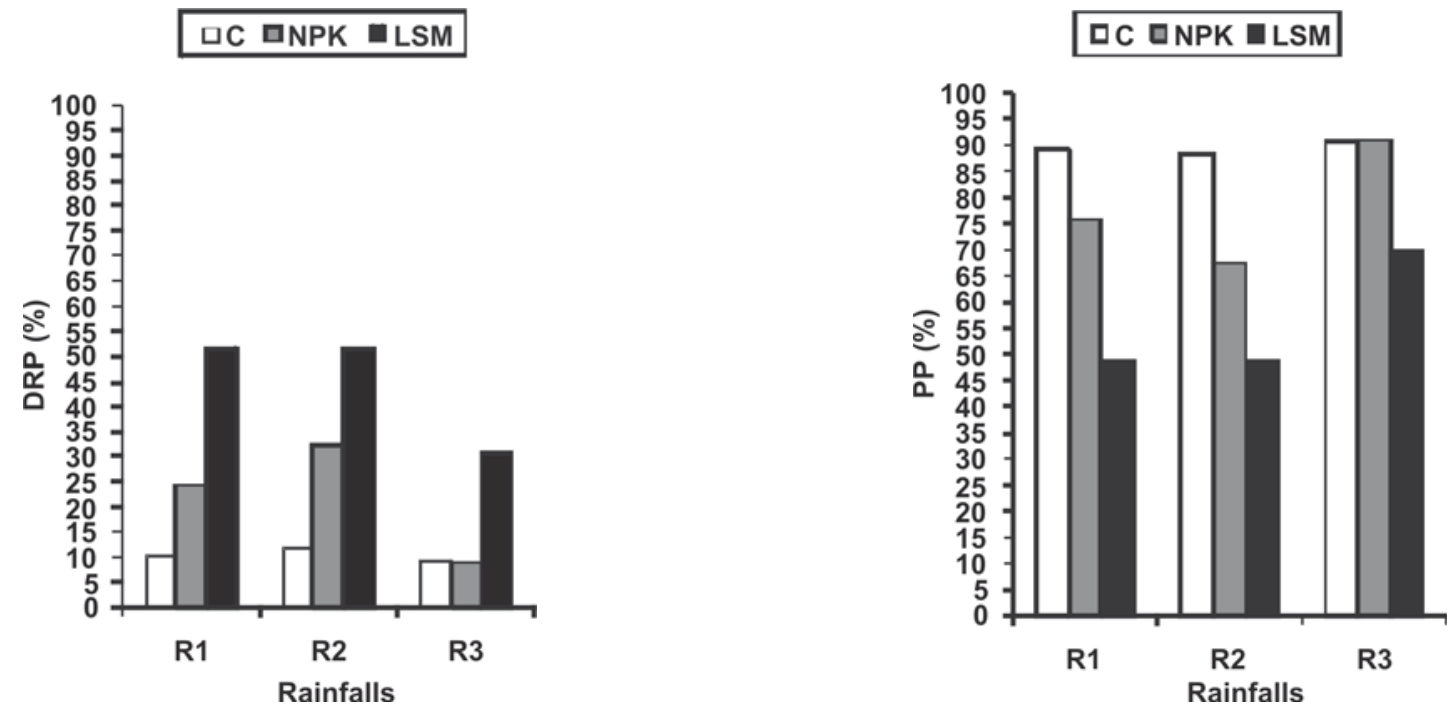

Figure 1 - Percentage of TP concentration as dissolved reactive P (DRP) and particulate P (PP) in surface runoff in the three simulated rainfalls (R1, R2, and R3) applied on the organic fertilization (LSM), mineral fertilization (NPK), and control (C).
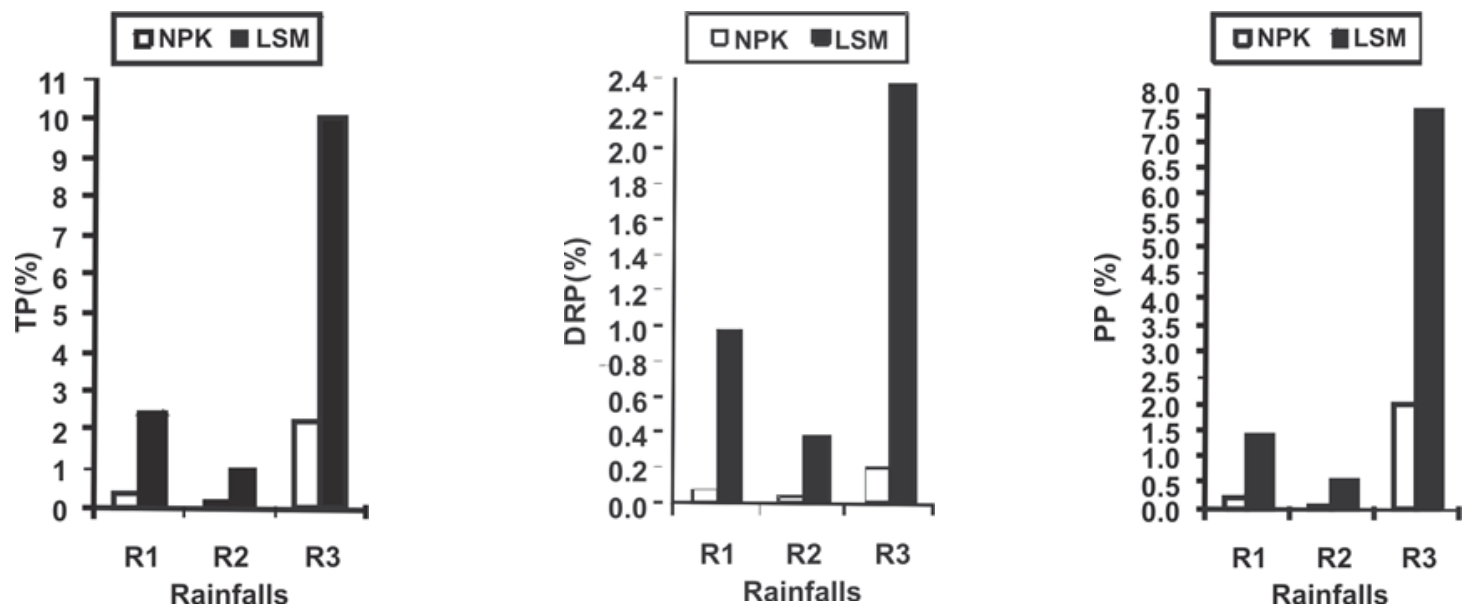

Figure 2 - Percentage of total $\mathrm{P}$ applied lost as total $\mathrm{P}(\mathrm{TP})$, dissolved reactive $\mathrm{P}(\mathrm{DRP})$, and particulate $\mathrm{P}$ (PP) in surface runoff in the three simulated rainfalls (R1, R2, and R3) on the organic fertilization (LSM) and mineral fertilization (NPK). 
Bertol et al.

al., 1994), which although can be meaningless agronomically may present serious environmental problems.

Comparing the rainfall intensities, there was a sharp influence of this factor in total P loss. For both fertilizations, the TP loss caused by the third rainfall $(117 \mathrm{~mm}$ $\mathrm{h}^{-1}$ ) was about $80 \%$ of the total loss (Figure 2). TP loss in the first rain was about twice that of the second rainfall, while the intensity of the first rainfall was just about $20 \%$ greater than intensity of the second rainfall. These show the combined effect of rainfall intensity and soil hydrological condition (Shigaki et al., 2007; Kleinman et al., 2006) on $\mathrm{P}$ transport. The application of liquid swine manure increased by $315 \%$ the TP lost in the third rainfall $\left(117 \mathrm{~mm} \mathrm{~h}^{-1}\right)$ compared with the first rainfall $(72$ $\mathrm{mm} \mathrm{h}^{-1}$ ). These differences reflect the effect of the runoff volume and the sediment concentration for the third and higher intensity rainfall.

The results from this study indicate a great potential of water contamination if the runoff from the notillage system reaches the water body, even from the areas without mineral and manure fertilization. So, it is recommended the use of vegetative and mechanical practices to control runoff (Foster, 1982), as plant cover, crop rotation, strip cropping, contour cultivation, and terraces (SEAB, 1994). Also it is fundamental to have the riparian vegetation considering the important role on the pollutants filtering (Smith et al., 1990).

\section{Conclusions}

The application at the soil surface, one day before the rain, of liquid swine manure at a rate of $60 \mathrm{~m}^{3} \mathrm{ha}^{-1}$ in no-till system, increased the concentrations and loads of dissolved reactive $\mathrm{P}$, particulate $\mathrm{P}$ and total $\mathrm{P}$ in runoff in comparison with the mineral fertilizer. In general, the most intense rainfall caused a greater concentration and load of $\mathrm{P}$ in runoff. These results show the great potential of water contamination by slurry application at the soil surface just before rain, and also show the importance to keep the runoff out of the streams by increasing the runoff infiltration in the agricultural field with best management practices, as plant cover, crop rotation, strip cropping, contour cultivation, terraces and riparian vegetation.

\section{References}

Alberts, E.E.; Spomer, R.G. 1985. Dissolved nitrogen and phosphorus in runoff from watersheds in conservation and conventional tillage. Journal Soil and Water Conservation 40: 153-157.

Allen, B.L.; Mallarino, A.R. 2008. Effect of liquid swine manure rate, incorporation, and timing of rainfall on phosphorus loss with surface runoff. Journal of Environmental Quality 37: 125137.

Andrade, F.V.; Mendonça, E.S.; Alvarez, V.H.; Novais, R.F. 2003. Adição de ácidos orgânicos e húmicos em Latossolos e adsorção de fosfato. Revista Brasileira de Ciência do Solo 27: 1003-1011.

American Public Health Association [APHA]. 1995. Standard Methods for the Examination of Water and Wastewater. 19ed. APHA, Washington, D.C., USA.
Baker, D.B.; Richards, R.P. 2002. Phosphorus budgets and riverine phosphorus export in northwestern Ohio watersheds. Journal of Environmental Quality 31: 96-108.

Bertol, O.J.; Rizzi, N.E.; favaretto, N.; Lavoranti, O.J. 2005. Perdas de nitrogênio via superfície e subsuperfície em sistema de semeadura direta. Revista Floresta 35: 429-443.

Bertol, O.J.; Rizzi, N.E.; Bertol, I.; Roloff, G. 2007. Perdas de solo e água e qualidade do escoamento superficial associadas à erosão entre sulcos em área cultivada sob semeadura direta e submetida às adubações mineral e orgânica. Revista Brasileira de Ciência do Solo 31: 781-792.

Bundy, L.G.; Andraski, T.W.; Powell, J.M. 2001. Management practice effects on phosphorus losses in runoff in corn production systems. Journal of Environmental Quality 30: 1822-1828.

Cassol, E.A.; Levien, R.; Anghinoni, I.; Badelucci, M.P. 2002. Perdas de nutrientes por erosão em diferentes métodos de melhoramento de pastagem nativa no Rio Grande do Sul. Revista Brasileira de Ciência do Solo 26: 705-712.

Conselho Nacional de Meio Ambiente [CONAMA]. Resolução n ${ }^{\circ}$ 357. Diário Oficial da União, Brasília, 18 mar. 2005.

Correll, D.L. 1998. The role of phosphorus in the eutrofication of receiving waters. Journal of Environmental Quality 27: 261-266.

Daniel, T.C.; Sharpley, A.N.; Lemunyon, J.L. 1998. Agricultural phosphorus and eutrophication: a symposium overview. Journal of Environmental Quality 27: 251-257.

Eghball, B.; Gilley, J.E. 1999. Phosphorus and nitrogen in runoff following beef cattle manure or compost application to no-till and tilled soil. Journal of Environmental Quality 28: 1201-1210.

Eghball, B.; Gilley, J.E. 2001. Phosphorus risk assessment index evaluation using runoff measurements. Journal Soil and Water Conservation 56: 202-206.

Empresa Brasileira de Pesquisa Agropecuária [EMBRAPA]. 1997. Manual de Métodos de Análise de Solo. 2ed. EMBRAPA-CNPS, Rio de Janeiro, RJ, Brazil.

Federer, W.T. 1993. Statistical Design and Analysis for Intercropping Experiments. 1. Two Crops. Springer, New York, NY, USA.

Foster, G.R. 1982. Modelling the erosion process. p.297-380. In: Haan, C.T.; Johnson, H.D.; brakensiek, D.L., eds. Hydrologic Modeling of Small Watersheds. American Society of Agricultural Engineers, St. Joseph, MI, USA.

Gilley, J.E.; Eghball, B.; Marx, D.B. 2007. Nutrient concentrations of runoff during the year following manure application. Transactions of the ASAE 50: 1987-1999.

Ginting, D.; Moncrief, J.F.; Gupta, S.C.; Evans, S.D. 1998. Interaction between manure and tillage system on phosphorus uptake and runoff losses. Journal of Environmental Quality 27: 1403-1410.

Hernani, L.C.; Kurihara, C.H.; Silva, W.M. 1999. Sistemas de manejo de solo e perdas de nutrientes e matéria orgânica por erosão. Revista Brasileira de Ciência do Solo 23: 145-154.

Ismail, I.; Blevins, R.L.; Frye, W.W. 1994. Long-term no-tillage effects on soil properties and continuous corn yields. Soil Science Society of America Journal 58: 193-198.

Jackson, M.L. 1958. Soil chemical analysis. 6ed. University of Wisconsin, Madison, WI, USA.

Kimmell, R.J.; Pierzynski, G.M.; Janssen, K.A.; Barnes, P.L. 2001. Effects of tillage and phosphorus placement on phosphorus runoff losses in a grain sorghum-soybean rotation. Journal of Environmental Quality 30: 1324-1330.

Kleinman, P.J.A.; Sharpley, A.N.; Moyer, B.G.; Elwinger, G.F. 2002. Effect of mineral and manure phosphorus sources on runoff phosphorus. Journal of Environmental Quality 32: 20262033.

Kleinman, P.J.A.; Srinivasan, M.S.; Dell, C.J.; Schimidt, J.P.; Sharpley, A.N.; Bryant, R.B. 2006. Role of rainfall intensity and hydrology in nutrient transport via surface runoff. Journal of Environmental Quality 35: 1248-1259.

Laflen, J.M.; Tabatabai, M.A. 1984. Nitrogen and phosphorus losses from corn-soybean rotations as affected by tillage practices. Transactions of the ASAE 27: 58-63. 
McDowell, L.L.; Sharpley, A.N. 2001. Phosphorus losses in subsurface flow before and after manure application to intensively farmed land. The Science of the Total Environment 278: 113-125.

Mori, H.F.; Favaretto, N.; Pauletti, V.; Dieckow, J.; Santos, W.L. 2009. Perda de água, solo e fósforo com aplicação de dejeto líquido bovino em Latossolo sob plantio direto e com chuva simulada. Revista Brasileira de Ciência do Solo 33: 189-198.

Parry, R. 1998. Agricultural phosphorus and water quality: a U.S. Environmental Protection Agency perspective. Journal of Environmental Quality 27: 258-261.

Peles, D. 2007. Perdas de solo, água e nutrientes sob aplicação de gesso e dejeto líquido de suínos. MSc. Dissertation. UFPR, Curitiba, PR, Brazil.

Pierson, S.T.; Cabrera, M.; Levanylo, G.K.; Kuykendall, H.A.C.; Hoveland, S.; McCcann, M.A.; West, L.T. 2001. Phosphorus and ammonium concentrations in surface runoff from grasslands fertilized with broiler litter. Journal of Environmental Quality 30: 1784-1789.

Pote, D.H.; Daniel, T.C.; Nichols, D.J.; Sharpley, A.N.; Moore, P.A.; Miller, D.M.; Edwards, D.R. 1999. Relationship between phosphorus levels in three ultisol and phosphorus concentrations in runoff. Journal of Environmental Quality 28: 170-175.

Quinton, J.N.; Catt, J.A.; Hess, T.M. 2001. The selective removal of phosphorus from soil is event size important? Journal of Environmental Quality 30: 538-545.

Royston, P. 1992. Approximating the Shapiro-Wilk W-test for nonnormality. Statistics and Computing 2: 117-119.

Secretaria de Estado da Agricultura e do Abastecimento [SEAB]. 1994. Manual Técnico do Subprograma de Manejo e Conservação do Solo. 2ed. SEAB, Curitiba, PR, Brazil.

Sharpley, A.N.; Menzel, R.G.; Smith, S.J.; Rhoades, E.D.; Olness, A.E. 1981. The sorption of soluble phosphorus by soil material during transport in runoff from cropped and grassed watersheds. Journal of Environmental Quality 10: 211-215.

Sharpley, A.N.; Troeger, W.W.; Smith, S.J. 1991. The measurement of bioavailable phosphorus in agricultural runoff. Journal of Environmental Quality 20: 235-238.

Sharpley, A.N.; Smith, S.J.; Jones, O.R.; Berg, W.A.; Coleman, G.A. 1992. The transport of bioavailable phosphorus in agricultural runoff. Journal of Environmental Quality 21: 30-35.

Sharpley, A.N.; Chapra, S.C.; Wedepohl, R.; Sims, J.T; Daniel, T.C.; Reddy, K.R. 1994. Managing agricultural phosphorus for protection of surface waters: issues and options. Journal of Environmental Quality 23: 437-451.
Sharpley, A.N.; McDowell, R.W.; Kleinman, J.A. 2001. Phosphorus loss from land to water: integrating agricultural and environmental management. Plant and Soil 237: 287-307.

Shigaki, F.; Sharpley, A.; Prochnow, L.I. 2006a. Animal-based agriculture, phosphorus management and water quality in Brazil: options for the future. Scientia Agricola 63: 194-209.

Shigaki, F.; Sharpley, A.; Prochnow, L.I. 2006b. Source-Related transport of phosphorus in surface runoff. Journal of Environmental Quality 35: 229-2235.

Shigaki, F.; Sharpley, A.; Prochnow, L.I. 2007. Rainfall intensity and phosphorus source effects on phosphorus transport in surface runoff from soil trays. Science Total Environmental 373: 334-343.

Simard, R.R.; Beauchemin, S.; Haygarth, P.M. 2000. Potential for preferential pathways of phosphorus transport. Journal of Environmental Quality 29: 97-105.

Smith, S.J.; Schepers, J.S.; Porter, L.K. 1990. Assessing and managing agricultural nitrogen losses to the environment. USDA Conservation \& Production Research Laboratory, Bushland, TX, USA.

Smith, K.A.; Jackson, D.R.; Withers, P.J.A. 2001. Nutrient losses by surface run-off following the application of organic manures to arable land. 2. Phosphorus Environmental Pollution 112: 5360.

Soileau, J.M.; Touchton, B.F.; Hajek, B.F.; Yoo, K.H. 1994 Sediment, nitrogen, and phosphorus runoff with conventional and conservation-tillage cotton in a small watershed. Journal Soil and Water Conservation 49: 82-89.

Sonzogni, W.C.; Chapra, S.C.; Armstrong, D.E.; Logan, T.J. 1982. Bioavailability of phosphorus inputs to takes. Journal of Environmental Quality 11: 555-562.

Steel, R.G.D.; Torrie, J.H.; Dickey, D.A. 1997. Principles and Procedures of Statistics: A Biometrical Approach. 3ed. McGrawHill, New York, NY, USA.

Swanson, N.P. 1965. Rotating boom rainfall simulator. Transactions of the ASAE 8: 71-72.

Withers, P.J.A.; Stephen D.; Clay, S.D.; Breeze, V.G. 2001. Phosphorus transfer in runoff following application of fertilizer, manure, and sewage sludge. Journal of Environmental Quality 30: $180-188$.

Received October 18, 2007

Accepted August 04, 2009 